\title{
Pemilihan Platform Media Pembelajaran Online Pada Masa New Normal
}

\author{
${ }^{1}$ Lukmanul Hakim \\ ${ }^{1}$ Fakultas Dakwah dan Komunikasi, UIN Walisongo Semarang, Indonesia \\ elhakim@walisongo.ac.id
}

\section{ARTICLE INFO}

\section{Article History:}

Received : 10-10-2020

Revised : 02-11-2020

Accepted : 09-11-2020

Online : 30-11-2020

\section{Keywords:}

Pembelajaran Online;

Media Pembelajaran;

Pembelajaran Daring.

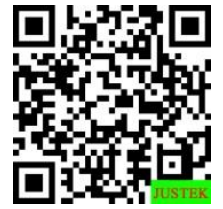

\begin{abstract}
Abstrak: Teknologi sangat berperan penting untuk mendukung sebuah pendidikan yang mampu mempercepat pemahaman. di era digiatal ini semua kegiatan/Aktiviatas menggunakan teknologi, hal itu terlihat dari perkembangan industri 4.0 memudahkan kita untuk mengakses segala informasi yang kita butuhkan, terutama didunia pendidikan. digitalisasi pendidikan yang dilakukan di Indonesia dengan mengembangkan pembelajaran online (daring). mengamati pembelajaran online membuat segala sesuatu serba cepat dan mudah diakses dimana pun. perlu dilakuakan penelitian platform media pembelajaran apa yang efektif, dan mampu mengakomodasi semua mahasiswa dalam pembelajaran online di masa New Normal. Metode penelitian menggunakan metode penelitian kualitatif yang didukung dengan pengambilan data survey dan melakukan analisis deskriptif kualitatif terhadap data dan informasi yang telah diperoleh dengan survey maupun sumber-sumber lain. Hasil yang diperoleh untuk pemilihan platform pembelajaran online meliputi : 1) pemilihan platform menggunakan WhatsApp dilihat sebesar terlihat dari hasil suvey sebesar $46,4 \%$ Lebih memilih karena Apliaksi mudah diakses, respon cepat dan hemat kuota. namun kekurangan aplikasi ini tidak bisa melakuka conference/meeting secara banyak (hanya dibatasi 8 Orang); 2) Pembelajaran Daring secara langsung (Live) menggunakan Line, hal tersebut terlihat dari survey sebesar $44,3 \%$ memilih, karena ketika pembelajaran secara langsung sinyal yang stabil, kapasitas untuk melakukan meeting yang tersedia lebih dari 100 orang dan tidak berbayar.
\end{abstract}

Abstract: Technology plays an important role in supporting an education that can accelerate understanding. In this digiatal era, all activities / activities use technology, this can be seen from the development of industry 4.0 making it easier for us to access all the information we need, especially in the world of education. digitalization of education carried out in Indonesia by developing online learning (online). observing online learning makes things fast paced and easily accessible anywhere. It is necessary to do research on what learning media platforms are effective and able to accommodate all students in online learning during the New Normal period. The research method uses qualitative research methods that are supported by taking survey data and conducting qualitative descriptive analysis of the data and information that has been obtained through surveys and other sources. The results obtained for the selection of an online learning platform include: 1) choosing a platform using WhatsApp as 
seen from the survey results of $46.4 \%$ Prefer because the application is easy to access, quick response and saves quotas. but the shortcomings of this application are not able to do a lot of conference / meeting (only limited to 8 people); 2) Direct online learning (Live) using Line, this can be seen from a survey of $44.3 \%$ choosing, because when direct learning has a stable signal, the capacity to conduct meetings is available for more than 100 people and is free of charge.

d.i Crossref

\section{A. LATAR BELAKANG}

Era disrupsi menjadi tantangan tersendiri bagi pendidik, dimana peran manusia lambat laun tergantikan posisinya oleh mesin sehingga pendidik mau tidak mau perlu menyambut era ini dengan menjadi pendidik disrupsi. Pengembangan diri dengan inovasi dan pembaharuan sangat penting dilakukan pendidik untuk berdaptasi (Setiawan \& Komalasari, 2020). Teknologi sangat berperan penting untuk mendukung sebuah pendidikan yang mampu mempercepat pemahaman. di era digiatal ini semua kegiatan/Aktiviatas menggunakan teknologi, hal itu terlihat dari perkembangan industri 4.0 memudahkan kita untuk mengakses segala informasi yang kita butuhkan, terutama didunia pendidikan. digitalisasi pendidikan yang dilakukan di Indonesia dengan mengembangkan pembelajaran online (daring). mengamati pembelajaran online membuat segala sesuatu serba cepat dan mudah diakses dimana pun. Awal tahun 2020 dunia digemparkan dengan Penyebaran wabah Corona Virus Desease 2019 (Covid-19), yang mengakibatkan sebuah perubahan belajar-mengajar di dunia pendidikan. hal tersebut membuat aktivitas tatap muka langsung berubah dengan cepat menggunakan pembelajaran online (daring) untuk mencegah penularan Covid-19 dengan cepat. Sejumlah kebijakan yang tidak biasa diambil oleh sejumlah kepala Negara di dunia, seperti menutup sekolah, rumah ibadah, tempat-tempat wisata namun tetap saja virus ini belum bisa dihentikan penyebarannya, Negara dipaksa untuk mengambil kebijakan yang lebih extrime lagi yaitu menutup wilayahnya, atau yang disebut dengan lock down (Iin, 2020).

Pemilihan media yang tepat dalam pembelajaran selama masa pendemi mampu menghasilkan output yang baik sesuai dengan kebutuhan dan kondisi yang ada. Pembelajaran secara virtual/daring/online yang menjadi tuntutan saat ini dapat menggunakan media daring. pembelajaran online diharapkan tidak menimbulkan kejenuhan, kebosanan baik dari pendidik maupun peserta didik, sehingga dalam kondisi belajar dari rumah tetap akan mencetak generasi yang unggul (Indiani, 2020). Pembelajaran daring dipilih sebagai alternatif pembelajaran jarak jauh untuk mengurangi potensi penyebaran virus. Namun begitu, muncul keraguan mengenai efektifitas pembelajaran berbasis daring dalam proses pembelajaran (Setiawan \& Komalasari, 2020). Persebaran Covid-19 yang masif membuat kegiatan belajar mengajar terdampak, serius bagi akademisi menjadi perhatian serius dalam proses pembelajaran. Pembelajaran 
online merupakan program ril penanganan dari manajemen krisis akut selama pandemi Covid-19. Penanganan dimasa krisis ini diberlakukan tidak hanya pada lembaga pemerintah, swasta ataupun pendidikan, akan tetapi untuk semua perusahaan.

Media pembelajaran online sangat beragam pilihannya, mulai dari hanya sekedar berkirim pesan (chatting) hingga media yang dapat menampilkan video atau melakukan video conference. Semua platform kelas online menawarkan berbagai fitur yang menarik serta mampu memudahkan pembelajaran online (Hidayat \& Noeraida, 2020). Media Pembelajaran daring yang bisa digunakan saat ini baik melalui aplikasi Whatsapp, elearning, Whatsapp group, goggle classroom, kelas maya, email, telegram, google form, zoom, Meet, Webex Meet dan lain-lain (Indiani, 2020). Belajar online bagi sebagian besar merupakan metode belajar baru dan tanpa direncanakan. Situasi ini terjadi dengan sedikit dipaksakan karena adanya pandemi Covid-19 (Hidayat \& Noeraida, 2020).

Mengamati efektifitas pembelajaran daring mempunyai teknis yang berbeda dari model pembelajaran system tatap muka yang dilakukan dengan pembelajaran full online serta memudahkan pelaksanaannya untuk mengakses dimana saja. Hal ini mengandalkan internet sebagai laju perkuliahan yang tidak hanya memudahkan para dosen dan mahasiswa dalam menentukan model komunikasi untuk pelaksanaan pembelajaran. Kegiatan pembelajaran daring yang berlangsung secara real time membuat pendidik memilih aplikasi yang tepat untuk keberlangsungan pembelajaran (Maulah et al., 2020).

Permasalahan yang timbul pada saat pelaksanaan pembelajaran tidak menutup kemungkinan terjadi dalam pembelajaran daring di rumah yang dialami para mahasiswa membuat pembelajaran tidak efektif. Permasalahan yang terjadi meliputi minimnya jaringan, Paket data (kuota Internet), ketersediaan perangkat pembelajaran (laptop, Smartphone), suasana rumah dan lingkungan sekitar yang tidak mendukung juga turut menentukan efektifitas pembelajaran daring. Kesulitan terbesar yang dialami mahasiswa yaitu tingkat pemahaman materi, karena gaya belajar pada masing-masing mahasiswa mempengaruhi tingkat pemahaman dalam penyerapan materi pembelajaran (Maulah et al., 2020). Maka, perlu adanya penelitian platform media pembelajaran apa yang efektif, dan mampu mengakomodasi semua mahasiswa dalam pembelajaran online pada masa New Normal.

\section{B. METODE PENELITIAN}

Pendekatan Penelitian ini menggunakan metode penelitian kualitatif yang bertujuan untuk mengetahui Pemilihan platform Media Pembelajaran Online pada masa New Normal. Penelitian ini menggunakan metode survey untuk memperoleh data yang dilakukan secara online. jenuh, dimana populasi yang ada Pengambilan data dilakukan dengan metode sampel seluruhnya dijadikan sampel (Jati, 2017). Pengumpulan data dilakukan melalui survei untuk memperoleh informasi berbentuk opini terkait pembelajaran daring yang dilaksanakan 167 Mahasiswa mata kuliah Ilmu Pariwisata di Fakultas Dakwah dan Komunikasi UIN Walisongo Semarang. Instrumen yang digunakan berupa angket survei yangdiisi secara online menggunakan aplikasi google form. Pertanyaan yang diajukan dalam survey yaitu tantang keterlaksanaan pembelajaran 
online, platform yang digunakan, kendala yang dihadapi dan jumlah pertemuan online yang dilaksanakan setiap minggu. Data tentang hasil survei dianalisis dengan teknik analisis deskriptif (Made Yeni, 2020).

\section{HASIL DAN PEMBAHASAN}

Penelitian ini berfokus pada Pemilihan platform media pembelajaran Online Pada Masa New Normal untuk mata kuliah Ilmu Pariwisata di Fakultas Dakwah dan Komunikasi UIN Walisongo Semarang, selama pandemic Covid-19 di Masa New Normal. pembelajaran daring mendorong mahasiswa untuk memperoleh Tambahan (suplemen) pengetahuan, Komplemen materi perkuliahan, dan Penggantian kuliah secara fleksibel (Yuniarti, 2010). Hasil analisis menunjukan bahwa kecendrungan mahasiswa dala memilih Platform untuk pembelajaran Online yang efektif, Meliputi :

\section{Gambaran Pembelajaran Daring}

a. Aplikasi Pembelajaran Daring

Aplikasi pembelajaran Daring yang digunakan pada matakuliah Ilmu Pariwisata Fakultas Dakwah dan Komunikasi UIN Walisongo Semarang berdasarkan Gambar 1. menunjukan bahwa kecendrungan mahasiswa menggunakan WhatsApp sebesar 46,1\%; line sebesar 13,8 \%; Google Classroom sebesar 6,1 \%; dan sisanya menggunakan aplikasi lain sebesar 34\%.

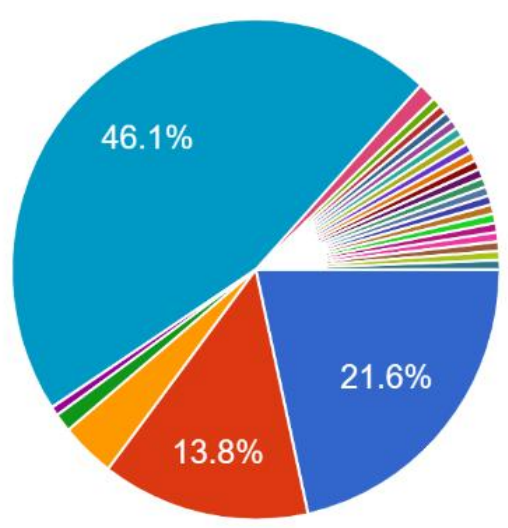

Gambar 1. Aplikasi Pembelajaran Online

\section{b. Pembelajaran Daring Secara Langsung (live)}

Pembelajaran Daring secara langsung (Live) yang digunakan pada matakuliah Ilmu Pariwisata Fakultas Dakwah dan Komunikasi UIN Walisongo Semarang berdasarkan Gambar 2. Menunjukan Bahwa Kecendrungan Mahasiswa Menggunakan Line sebesar 44,3 \%; YouTube Sebesar 15,6\%; zoom Sebesar 12,6 \%; Googlemeet sebesar 12 \%; WhatsApp Sebesar 11, 4\%; serta Instagram dan google classroom sebesar 4,1\%. 


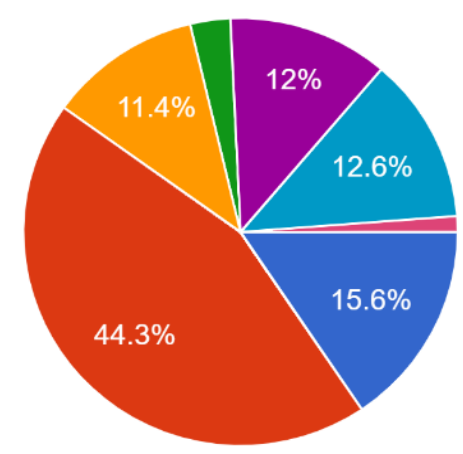

Gambar 2. Pembelajaran Daring Secara Langsung (Live)

c. Pembelajaran Daring dengan penggunaan kuota sedikit

Pembelajaran Daring dengan penggunaan kuota sedikit yang digunakan pada mata kuliah Ilmu Pariwisata Fakultas Dakwah dan Komunikasi UIN Walisongo Semarang berdasarkan Gambar 3. Menunjukan Bahwa Kecendrungan Mahasiswa Menggunakan WhatsApp sebesar 76,6 \%; Line Sebesar 15,6\%; google classroom sebesar 3,6\% ; Moodle Sebesar 1,2 \%; dan Menggunakan Platform lain sebesar 2,7\%.

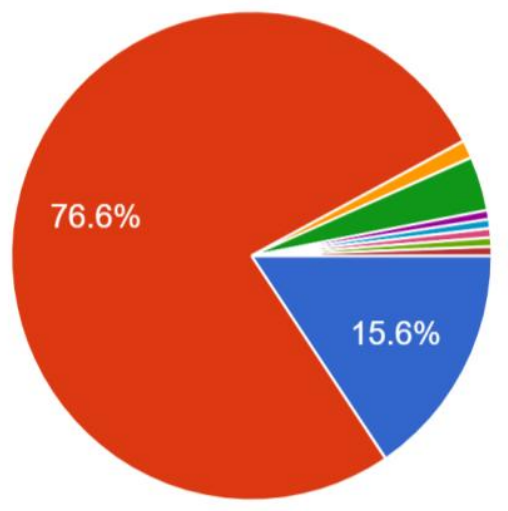

Gambar 3. Pembelajaran daring dengan penggunaan Kuota sedikit

\section{Metode Pembelajaran Daring}

Model pembelajaran daring yang ditinjau dari model komunikasi dengan pendekatan penggunaan media belajar, mahasiswa lebih memilih aplikasi WhatsApp yang dianggap paling efektif karena sudah digunakan dalam kehidupan sehari-hari sehingga mudah dalam pengoperasiannya. sedangkan media komunikasi yang sering digunakan komunikasi semi dua arah pembelajaran yang biasanya dalam bentuk gambar, power point, video, dan lain-lain, karena metode ceramah saja tidak cukup dalam pembelajaran (Maulah et al., 2020).

Menurut (Marbun, 2020) Pemilihan model dan disain harus memperhatikan kekhasan mata kuliah yang diajarkan. Kondisi covid-19 mengharuskan dosen memilih 
pembelajaran online. Ada lima pilihan model pembelajaran antara lain: pembelajaran berbasis proyek, teknologi informasi komunikasi (TIK), penelitian, masalah dan modul dan juga ada empat disain pembelajaran yakni: ADDIE (analysis, design, development,implementation dan evaluation), ABCD (Audience, Behaviour, Conditions Dan Degree). POE2WE (Prediction, Observation, Explanation, Ellaboration, Write dan Evaluation),dan ROPES (Review, Overview, Presentation,Excercise dan Summary). Dengan mengimplementasikan model dan disain pembelajaran di atas, pembelajaran bergeser dari teacher center menjadi student center berbasis online.

Menurut (Mustakim, 2020) Metode Pembelajaran online agar lebih efektif Agar mahasiwa mampu memahami adalah :

a. Pembelajaran dilakukan melalui video call.

b. Pemberian materi pembelajaran yang ringkas.

c. Meminimalisir mengirim materi dalam bentuk video berat untuk menghemat kuota.

d. Pemilihan materi dalam video harus berdasarkan kriteria bahasa yang mudah dipahami.

e. Tetap memberikan materi sebelum penugasan, dan.

f. Pemberian soal yang bervariatif dan berbeda tiap peserta didik.

g. Pemberian tugas harus disertakan cara kerjanya.

h. Memberikan tugas sesuai dengan jadwal pelajaran.

i. Mengingatkan peserta didik jika ada tugas yang diberikan.

j. Mengurangi tugas.

Metode Pembelajaran daring yang sesuai dengan hasil penelitian yang terlihat dalm Gambar 1. Diperoleh menggunakan Aplikasi WhatsApp Karena Model pembelajaran daring tersebut memiliki efektifitas dalam mengakses informasi/kuliah secara cepat, mudah dan langsung bias ditanggapin oleh dosen. Metode pembelajaran ini dengan cara : Membuat sebuah panduan dan pelaksanaan pembelajaran yang simple dan jelas, memberikan ruang diskusi lebih update dan mampu ditanggapi secara langsung,Media yang digunakan simple dan mudah dimengerti mahasiswa.

\section{Media Pembelajaran Daring}

Media pembelajaran daring pada mata kuliah Ilmu Pariwisata Berdasarkan tingkat kemudahan mahasiswa dalam pembelajaran daring meliputi :

a. WhatsApp

Aplikasi WhatsApp Group merupakan Sarana Untuk pembelajaran yang sangat efektif, efisien dan mudah digunakan disemua kalangan serta familiar sehingga tidak membutuhkan waktu untuk beradaptasi lagi dengan program yang baru. hal ini dapat dilihat dari mahasiswa cendrung memilih WhatsApp sebesar 46,1\% dan secara penggunaan kuota $76,6 \%$ ini menjadi pilihan mahasiswa menggunakanya.

b. Line

Aplikasi Line platform media social memberikan vitur conference / meeting secara live, penggunaan kapasitas orang pun mampu lebih dari 100 orang dan mudah digunakan dimanapun. hal tersebut bisa kita lihat dari gambar 1. bahwa mahasiswa yang 
mengikuti mata kuliah Ilmu Pariwisata Cendrung mengunakan line sebesar 44,3\% sehingga pemilihan kulaiah secara live menjadi nyaman dan sinyal stabil.

c. YouTube

YouTube juga menjadi salah satu media yang dimanfaatkan oleh dosen untuk pembelajaran secara darring. Mahasiswa dapat mengakses video yang relevan dengan topik pembelajaran yang dipelajari. mahasiswa memilih ini karena ketika sinyal tidak stabil bisa diputar ulang yang menjadi pemilihan aplikasi.

\section{d. Google Classroom}

Google Classroom merupakan media yang kurang diminati oleh mahasiswa dalam melaksanakan Pembelajaran Daring, Karena Banyaknya mahasiwa mengeluh ketika sinyal tidak stabil membuka dan mengakses aplikasi tersebut sedikit sulit, namun secara fitur sangat mendukung. Platform ini memberikan fasilitas untuk melakukan komunikas interaktif dalam bentuk teks (Damayanti, 2020).

e. Zoom

Aplikasi Zoom untuk melaksanakan Pembelajaran Daring. Aplikasi ini memungkinkan mahasiswa dan dosen untuk bertatap muka secara online sehingga dosen dapat memberikan instruksi dan menjelaskan materi ajar secara langsung.

Berkolaborasi dalam mendukung pembelajaran online mampu memberikan sebah terobosan atau temuan untuk memudahkan pembelajaran secara online (Sudarsana \& dkk, 2020). Peran media massa ataupun komunikasi massa diperlukan sebagai salah satu langkah solutif dalam penyelesaian akibat dampak yang ditimbulkan oleh pandemi Covid19 ini (Syaipudin, 2020). Pelaksanaan pembelajaran daring memungkinan mahasiswa dan dosen melaksanakan perkuliahan dari rumah masing-masing. Mahasiswa dapat mengakses materi perkuliahan dan mengirim tugas yang diberikan dosen tanpa harus bertemu secara fisik di kampus. Tindakan ini bisa mengurangi timbulnya kerumunan massa di kampus seperti yang terjadi pada perkuliahan tatap muka (Sadikin \& Hamidah, 2020).

Aspek keterhubungan dan aspek pembelajaran pada pembelajaran daring menggunakan WhatsApp group dengan menerapkan konsep Community of Inquiry dirasakan oleh mahasiswa lebih tinggi dibandingkan dengan menggunakan webinar Zoom. Selain itu, 98\% mahasiswa lebih memilih menggunakan whatsapp group untuk digunakan dalam pembelajaran daring pada masa pandemi Covid-19 (Yulianto et al., 2020). Dalam hal media (sarana) pembelajaran daring, berdasarkan hasil wawancara tidak langsung sebagian besar menggungkan WhatsApp sebagai platform atau aplikasi yang paling mudah dan nyaman digunakan (Dewi, 2020).

Pelaksanaan pembelajaran daring berjalan dengan lancar, namun dirasakan sebagian besar dosen dan mahasiswa kurang ideal dibandingkan pembelajaran tatap muka secara konvensional. Komunikasi terjalin kurang lancar menyebabkan materi menjadi sulit dipahami terutama mata kuliah praktikum. Hasil belajar mahasiswa dengan pembelajaran daring bervariasi, mulai dari kurang memuaskan, cukup hingga baik. kendala yang dihadapi mahasiswa dan dosen dalam pembelajaran daring adalah : ketersediaan kuota internet, jaringan yang terkadang tidak stabil, dan alat penunjang (Gawai dan Laptop)(Rosali, 2020). 
Menurut (Damayanti, 2020) Faktor-faktor yang perlu diperhatikan dalam Pembelajaran Online, meliputi:

1. Aksesibilitas media menjadi factor penting yang menentukan apakah menggunakan media atau tidak. pembelajaran online harus memiliki aksebilitas yang mudah

2. Perangkat media yang didukung harus mampu berbagi macam media, seperti ; audio, video, audio, dan bahkan audiovisual.

3. Fitur komunikasi yang tersedia di suatu LMS dan platform e-learning menjadi salah satu faktor pertimbangan bagi pendidik dalam memilih media e-learning. Semakin banyak fitur komunikasi yang disediakan maka akan ada kecenderungan pengguna untuk memilihnya.

4. Proses dan Jenis penilaian Jenis dan sistem penilaian yang disediakan oleh media $e$ learning merupakan faktor penting dalam memilih suatu media untuk melaksanakan e-learning.

5. Desain juga turut menjadi bahan pertimbangan bagi responden untuk memilih suatu media e-learning.

6. Harga, beberapa platform e-learning mengharuskan penggunanya untuk membayar sejumlah harga atau berlangganan untuk menikmati beberapa fitur tambahan yang disediakan. Dilihat dari media yang digunakan, maka responden cenderung memilih media e-learning yang tidak berbayar, seperti Google Classroom, Edmodo, Zoom, dan WhatsApp serta YouTube.

Pemilihan Platform pembelajaran Daring ini sangat didasari harus memenuhi paradigma baru yang mampu melaksanakan pembelajaran secara efektif :

1. Perubahan cara pandang, kebiasan pembelajaran awalnya tatap muka berubah menjadi online ini perlu melihat /memandang dengan visioner agar mampu menguasi materi dengan baik .

2. Perangkat/aplikasi yang banyak digunakan smartphone yang menjadikan pertimbangan pengguna mampu menggunakan secara mudah dan nyaman.

3. Perangkat media pembelajaran yang mendukung secara visual, audio dan live dalam menjalankan pembelajaran daring

4. fleksibel dan mudah untuk membaca, mengerjakan dan melakukan live pembelajaran daring, hal ini menjadi poin penting dalam menggunakan platform pembelajaran daring.

Dari Hasil Analisis Pemilihan Platform Pembelajaran Online dimasa New Normal menggunakan :

1. Aplikasi WhatsApp terlihat dari hasil suvey sebesar $46,4 \%$ Lebih memilih karena Apliaksi mudah diakses, respon cepat dan hemat kuota. namun kekurangan aplikasi ini tidak bisa melakuka conference/meeting secara banyak (hanya dibatasi 8 Orang).

2. Pembelajaran Daring secara langsung (Live) menggunakan Line, hal tersebut terlihat dari survey sebesar 44,3\% memilih, karena ketika pembelajaran secara langsung sinyal yang stabil, kapasitas untuk melakukan meeting yang tersedia lebih dari 100 orang dan tidak berbayar.

3. Pemilihan Media Pembelajaran Daring secara umum Mahasiswa pada mata kuliah Ilmpu Pariwisata di Fakultas Dakwah dan Komunikasi UIN Walisongo semarang lebih 
memilih Menggunakan WhatsApp group, Dibandingkan menggunakan E-learning kampus yang masih banyak kendala dalam proses pembelajaran.

\section{SIMPULAN DAN SARAN}

Pemilihan Platform Pembelajaran Online dimasa New Normal menggunakan (1) Aplikasi WhatsApp terlihat dari hasil suvey sebesar 46,4\% Lebih memilih karena Apliaksi mudah diakses, respon cepat dan hemat kuota. namun kekurangan aplikasi ini tidak bisa melakuka conference/meeting secara banyak (hanya dibatasi 8 Orang); (2) Pembelajaran Daring secara langsung (Live) menggunakan Line, hal tersebut terlihat dari survey sebesar 44,3\% memilih, karena ketika pembelajaran secara langsung sinyal yang stabil, kapasitas untuk melakukan meeting yang tersedia lebih dari 100 orang dan tidak berbayar; (3) Pemilihan Media Pembelajaran Daring secara umum Mahasiswa pada mata kuliah Ilmpu Pariwisata di Fakultas Dakwah dan Komunikasi UIN Walisongo semarang lebih memilih Menggunakan WhatsApp group, Dibandingkan menggunakan E-learning kampus yang masih banyak kendala dalam proses pembelajaran.

Penelitian kedepan Mampu membuat sebuah Aplikasi atau Platform yang mampu digunakan secara mudah, murah, Aktual dan efisien dalam melakukan pembelajaran dengam memberikan saran : Harus menglakuakan analisis penggunaan sesuai kebutuhan, mampu mengkombinasikan antara audio visual secara real team yang membuat pengguna tertarik dan memakai media ini.

\section{REFERENSI}

Damayanti, L. S. (2020). Implementasi E-Learning Dalam Pembelajaran Bahasa Inggris Di Pendidikan Tinggi Pariwisata Di Bali Selama Pandemi Covid-19. Journey, 2(2), 63-82.

Dewi, M. S. (2020). Sequential Exploratory: Pembelajaran Seni Tari Bagi Calon Guru Madrasah Ibtidaiyah Di Masa Pandemi Covid-19. Elementerls: Jurnal Ilmu Pendidikan Dasar Islam, 2 No. $1 \mathrm{Me}(2655-6324), 1-7$.

Hidayat, D., \& Noeraida. (2020). Pengalaman Komunikasi Siswa Melakukan Kelas Online Selama Pandemi Covid - 19. JIKE Jurnal IImu Komunikasi Efek, 3(1), 172-182. https://doi.org/10.32534/jike.v3i2.1017

Iin, K. S. (Universitas. (2020). Perlindungan Negara Bagi Pengungsi Pada Masa Pandemi Global COVID-19: Kajian Hukum Internasional. Al-Azhar Islamic Law Review, 2(2656-6133), 66-77. https://doi.org/https://doi.org/10.37146/ailrev.v2i2.27

Indiani, B. (2020). Mengoptimalkan Proses Pembelajaran Dengan Media Daring pada Masa Pendemi COVID-19. 1(3), 227-232.

Made Yeni, S. (2020). Variations of Models and Learning Platforms for Prospective Teachers During the COVID-19 Pandemic Period. Indonesian Journal of Teacher Education, 1(2), 61-70. https://corona.ntbprov.go.id/

Marbun, P. (2020). Disain Pembelajaran Online Pada Era Dan Pasca Covid-19. CSRID Journal, 12(2), 129-142. http://csrid.potensi-utama.ac.id/index.php/CSRID/article/view/408

Maulah, S., Nurul a, F., \& R. Ummah, N. (2020). Perkuliahan Daring Sebagai Sarana Pembelajaran Selama Pandemi Covid-19. Alveoli : Jurnal Pendidikan Biologi, 1 No.2 Jul(1), 50-61.

Mustakim. (2020). Efektivitas Pembelajaran Daring Menggunakan Media Online Selama Pandemi Covid-19 Pada Mata Pelajaran Matematika the Effectiveness of E-Learning Using Online Media During the Covid-19 Pandemic in Mathematics. Al Asma: Journal of Islamic Education, 2(1), 1-12.

Rosali, E. S. (2020). Aktifitas Pembelajaran Daring Pada Masa Pandemi Covid-19 Dijurusan 
Pendidikan Geografi Universitas Siliwangi Tasikmalaya. Geography Science Education Journal (GEOSEE), 1 No.1 Jun, 21-30.

Sadikin, A., \& Hamidah, A. (2020). Pembelajaran Daring di Tengah Wabah Covid-19. BIODIK: Jurnal Ilmu Pendidikan Biologi, 6(2), 214-224. https://doi.org/10.17509/t.v6i2.20887

Setiawan, R., \& Komalasari, E. (2020). Membangun Efektifitas Pembelajaran Sosiologi Di Tengah Pandemi Covid-19. In Jurnal Ilmiah Penelitian Pendidikan Dan Sosiologi (Vol. 4, Issue 8).

Sudarsana, I. K., \& dkk. (2020). COVID-19: Perspektif Pendidikan (Issue October).

Syaipudin, L. (2020). Peran Komunikasi Massa Di Tengah Pandemi Covid-19. Kalijaga Jurnal of Komunikasi, 2(1), 14-34.

Yulianto, E., Cahyani, P. D., \& Silvianita, S. (2020). Perbandingan Kehadiran Sosial dalam Pembelajaran Daring Menggunakan Whatsapp group dan Webinar Zoom Berdasarkan Sudut Pandang Pembelajar Pada Masa Pandemic COVID-19. 3(2), 331-341.

Yuniarti, R. D. (2010). Potensi E-Learning Melalui Sistem Kuliah On-Line Dalam Meningkatkan Kualitas Pembelajaran Di Prodi Tata Niaga Jurusan Pendidikan Ekonomi FPEB-UPI. Manajerial, 8 No. 16 J, 66-77. 